\title{
Translating the vernacular: Indigenous and African knowledge in the eighteenth-century British Atlantic
}

\author{
Kathleen S. Murphy
}

\begin{abstract}
Encounters between diverse peoples and knowledges were one of the defining features of the early modern Atlantic world. This article examines some of the implications of these encounters by focusing on the place of indigenous and African knowledge in eighteenth-century natural histories of British plantation societies (from the Chesapeake to the Caribbean). It builds on recent scholarship to argue that while colonials acknowledged the authority of their black and indigenous informants as experts about American nature, they represented such expertise as merely the raw materials out of which they fashioned new natural knowledge. Naturalists credited their informants not as individual authors, but as members of groups whose collective experiences and observations gave them unique understanding of New World nature. Colonial naturalists appropriated such expertise while simultaneously asserting that it represented mere know-how, rather than genuine knowledge. Colonials suggested that their own ways of knowing were necessary in order to turn the collective know-how of enslaved and free Africans and Amerindians into stable, universal knowledge suitable for enlightened European audiences. By translating vernacular knowledge into a universal key, colonials suggested that they became authors of new matters of fact about American nature.
\end{abstract}

Keywords: British Atlantic; vernacular knowledge; plantation societies; natural history

Over the past decade, scholars have begun to uncover the myriad ways free and enslaved blacks, Amerindians, and others dismissed by naturalists as the "vulgar" contributed to the study of the natural world in the early modern Atlantic. This literature points to an epistemological flexibility in the eighteenth century, in which access to American natural curiosities partially mitigated racist or environmental biases against American testifiers, including those of indigenous and African descent. ${ }^{1}$ Such an explanation, however, fails to explain the ways in which the presence of black and indigenous informants lent epistemological authority to colonials' texts about the natural world. While desire for New World nature helped naturalists justify the inclusion of some indigenous and African knowledge, how did colonials understand their role in the process of knowledge production? In this site of intercultural encounters, what counted as knowledge?

Focusing on British plantation societies from the Chesapeake to the Caribbean during the first three-quarters of the eighteenth century, this article examines what Simon Schaffer has called the "process by which authorship is attributed to matters of fact." Invaluable recent scholarship in the history and sociology of science has explored the ways in which early modern natural philosophers relied on their social 
status and social networks to establish the legitimacy and credibility of their claims. ${ }^{3}$ This work, however, is overwhelmingly concerned with Europe, especially England. How these issues of credibility and authorship played out on the other side of the Atlantic is a question that is only beginning to be addressed. Although colonial naturalists drew upon European models and ideas, the plantation societies of the Atlantic were far removed from the homosocial world of London gentlemen. In British colonies from Maryland to Barbados, many - perhaps most - of those collecting specimens and testifying to the virtues of the natural world were of African or Amerindian descent.

The study of the natural world of the British Atlantic in the eighteenth century was one involving a diverse range of historical actors. The work of Susan Scott Parrish, in particular, demonstrates that while metropolitan propaganda would seem to preclude the possibility of free and enslaved blacks, Native Americans, women, and even white colonial men as reliable testifiers, in practice European science depended upon such informants. ${ }^{4}$ Enslaved and free blacks and Amerindians were seen as both uniquely knowledgeable about the natural world and potentially dangerous as a result of this knowledge. Colonials therefore served as buffer zones "between the metropolitan place of knowledge ratification and the volatile site of exotic secrets." their role in the buffer zones between their metropolitan audience and their local informants as the key place where new knowledge about the natural world of British America was created. It focuses on the category of local knowledge that colonials often characterized as "vulgar" knowledge; in eighteenth-century British plantation societies, this primarily referred to that belonging to people of Amerindian and African descent. While colonials acknowledged the authority of their black and indigenous informants as experts about American nature, they represented such expertise as merely the raw materials out of which they fashioned new natural knowledge. Colonial naturalists suggested that it required their verification and experimentation to transform the local expertise of their informants into stable, universal knowledge suitable for European audiences. By translating local knowledge into a universal register, colonials laid claim to the status of authors of new knowledge about American nature.

\section{Authority and authorship in the American vernacular}

The Maryland physician Richard Brooke was no stranger to the transatlantic circuits of natural history. In 1762, the physician sent the Society of Arts a sample of a tea made from the "red-root" shrub that, he promised, could take the place of Chinese tea while providing additional health benefits. This letter was part of a series of missives that Brooke contributed to metropolitan societies and publications describing New World nature, letters that built his transatlantic reputation as a curious gentleman. ${ }^{6}$ In his 1762 letter to the Society of Arts, Brooke claimed that the tea provided "wonderful Relief in obstinate Coughs," "raise[d] the Spirits in vapourish People, and occasion[ed] better rest." The physician reported that he learned of this tea from an unnamed Native American 20 years earlier, but he characterized himself as "the first and only Person who ever prepared this tea." Personhood, in this case, seemed only to have applied to Europeans or EuroAmericans. By disregarding the personhood of the Native American who first shared 
the remedy with him, Brooke simultaneously highlighted the indigenous source of his knowledge claim and proclaimed himself as author of it. Asserting the right to name the tea as the "first" person to discover it, Brooke "has taken the Liberty to call it Mattapany, which is the Indian name of the Place where he was born." He added that if his tea should prove popular with "the ladies in England," it would give him "great Pleasure to think that Mattapany will frequently be pronounced by the prettiest lips in the Universe."7 The term "Mattapany" primarily highlighted Brooke's personal history, rather than memorializing the Native American who revealed the virtues of the root. As such, it emphasized the indigenous origin of the tea while placing Brooke at the center as the author of this new matter of fact.

Brooke's letter regarding Mattapany tea is useful for thinking about authority, authorship, and vernacular knowledge in British plantation societies. Brooke did not deny the indigenous source of the natural knowledge that he reported to the Society of Arts; to the contrary, he highlighted its origins. But while the physician recognized the authority of his unnamed indigenous informant to understand the natural properties of the red-root, he did not represent the Native American as the individual who should be credited for the introduction of this new knowledge claim. Instead, Brooke placed himself in the role of author. He did so by verifying its efficacy, reporting it to the London society, and providing samples of the shrub so that the society's members could test the tea for themselves. ${ }^{8}$ Brooke thereby transformed local American knowledge into a form that his European audience would have seen as acceptable, stable, and even universal.

In theory, if not in practice, individuals of indigenous and African descent had no authority to speak as experts about American nature. In personal correspondence, planters' diaries, colonial law books, and natural philosophical texts, colonials decreed their own superior understanding of the natural world and the inability of those of African or Amerindian descent to authorize facts. Colonists like the Virginia planter Landon Carter, for example, made sweeping judgments, such as "A negroe can't be honest," that linked credibility to race. Colonial law not only defined slaves as property, but also assigned a range of legal disabilities to all individuals of Amerindian or African descent. Chief among these was the inability to testify in court, even when the sole witness to a crime.'

Despite the many pronouncements to the contrary, for colonists such as Brooke the authority of Amerindians and blacks regarding New World nature was critical to the success of British plantation societies. Colonists relied on the expertise of Amerindians and free and enslaved blacks to tend fields, heal the sick, serve as pathfinders and guides, navigate local waterways, prepare food, and perform a host of other duties that relied on detailed local knowledge about the natural world. Knowledge of the medicinal and culinary properties of local plants, in particular, was a practical necessity. Enslaved Africans adapted their rich heritage of herbalism and healing to their new environment by incorporating familiar plants introduced to the New World by slaving voyages with American substitutes for other African simples (botanical medicines). By the eighteenth century, Native American medical knowledge combined traditional healing practices with more recent adaptations made in response to a changing world. Colonial observers praised, in particular, indigenous skill with simples. Although colonists might have written dismissively of indigenous or African healing traditions, many also sought out such healers to treat the unfamiliar ailments with which they were confronted in the New World. In the 
Caribbean, even white attitudes to obeah were, in practice, much more ambivalent than colonial law and official communications with the metropole might suggest. The success of plantations relied on the appropriation of both the labor and the specialized agricultural knowledge of enslaved Africans, whether to grow crops long cultivated in Africa, such as rice, or others introduced from elsewhere, such as sugar. From the rice field to the sick room, the authority of Amerindians and free and enslaved blacks to speak locally as experts about American nature was reaffirmed daily. $^{10}$

Yet it was quite another thing to be represented as the author of new scientific knowledge before a European audience. To the contrary, the language employed by colonials to describe the expertise of their informants reflected the idea that theirs was knowledge situated in a particular place, and, in its current form, not capable of further transmission. In particular, colonial naturalists' frequent use of the word "vulgar" suggests this idea of boundedness.

In order to place boundaries around their own knowledge, colonials often used the word "vulgar" to describe both their indigenous and African informants, and the knowledge they possessed. Colonial naturalists" use of the word "vulgar" reflected common early modern usage, adapted to the colonial context. When colonials used "vulgar" to describe their informants, they invoked one of the contemporary understandings of the "vulgar" as the common people, particularly the uneducated and those of a low social rank. In British plantation societies, such an idea was racialized and primarily associated with individuals of African or Amerindian descent. Colonists contrasted the untrustworthy "vulgar" with trusted authorities, including, of course, themselves. The minister and naturalist of Barbados, Griffith Hughes, for example, decried "the Inadvertency and credulous Propensity of the Vulgar ... to believe every Story, that hath something marvelous in it."11 The meaner sort, according to this way of thinking, had a tendency to believe all claims, while Hughes implied that he could distinguish between vulgar errors and matters of fact. Colonial naturalists also employed "vulgar" to indicate the local or common names and uses associated with a particular animal or plant. For example, in 1714, John Lawson described the "Tortois, vulgarly call'd Turtle; I have rank'd these among the Insects, because they lay Eggs, and I did not know well where to put them." Similarly, the Jamaican surgeon Henry Barham explained that the plant the physician and then secretary of the Royal Society Hans Sloane had described as "Apocynum exectum folio Oblongo, flore umbellato, petalis coccinois reflenis," was in Jamaica "Vulgarly or Commonly Called Horse Blood Flower for its Great Vertues in Stopping of Blood.", "Vulgar" used in this way suggests the idea of the vernacular, in the sense of the common language spoken in a particular area.

Just as a vernacular language could only circulate within a local region and required translation into a more universal language (such as Latin) before it could cross borders, so too did local knowledge require transmutation before becoming translocal. The regularity with which naturalists in the British Atlantic employed the term "vulgar" suggestively recalls the category of "vernacular knowledge" employed recently by Helen Tilley. As Tilley has argued, "vernacular knowledge" helpfully highlights "the issues of linguistic and cultural specificity, while also reminding us of the various tensions between universal and particular truth claims."13 In the case of the British Atlantic, such tensions arose from the process by which colonials 
refashioned local knowledges into a universal form and, by so doing, positioned themselves as authors of new knowledge about American nature. ${ }^{14}$

\section{Anonymous individuals and corporate knowers}

As in the case of Brooke and the Mattapany tea, colonial naturalists typically acknowledged the indigenous or African origins of a particular knowledge claim but almost never represented the informant as the author of such knowledge. They understood individuals of African and indigenous descent to be members of communities which possessed valuable secrets about New World nature. For example, in 1733, Gilbert Falconer of Kent County, Maryland, declared that: "The Indians have many valuable Secrets among them, that are not yet communicated to the English, and perform several notable cures." The Jamaican historian James Knight similarly thought it would "not [be] below our Physicians to Enquire into [the] many Secrets in the Art of Physick, [that] may be obtained from those Negro Doctors." 15 The authority accorded to indigenous and African knowledge in colonials' letters and publications hinged on the perception of blacks and Amerindians as members of communities with privileged access to American nature, rather than on their credibility as individual knowers. In case after case, colonials noted the indigenous or African origins of the knowledge claims they reported, but failed to name the particular individual who served as their informant.

In contrast, the "vulgar" collaborators of early modern English natural philosophy were not merely anonymous but also invisible. Steven Shapin's history of what he calls the "invisible technicians" argues that the legitimacy of knowledge claims depended upon obscuring the work of "vulgar" assistants. The celebrated natural philosopher Robert Boyle employed dozens of laboratory assistants, domestic servants, and family members not only in the laboratory's physical labor, but also in the more interpretative work of making observations, recording data, and designing further experiments. Shapin argues that Boyle - sickly and almost blind by the end of his life - was likely not even present for many of the experiments he described and took authorial credit for in his publications. Although Boyle's laboratory assistants performed most of the experimental labor, they were "ghosts" at the machine, whose contributions remained nearly invisible in the published historical record. The hallmark of an assistant was his anonymity and invisibility in publications. Assistants were, in Shapin's phrase, "antiauthors," the printed acknowledgement of whose work would undermine the epistemological authority of the account. ${ }^{16}$

For naturalists in eighteenth-century British plantation societies, enslaved and free Africans and Amerindians represented the crucial collaborators without whom new natural knowledge could not be created. Yet unlike Boyle's laboratory assistants, individuals of African and indigenous descent were never spectral in natural histories of the British Atlantic. Rather than being antiauthors who left almost no trace in published accounts, black and indigenous informants' presence in colonials' publications and correspondence lent epistemological authority to their texts. As Parrish has argued, some claims even required indigenous or African origins in order for them to be credible. ${ }^{17}$ That colonial naturalists relied on $a$ person of Amerindian or African descent is made clear in their various texts, yet the identity of the 
particular informant was rarely provided. While assistants of African or Amerindian descent were not invisible, they remained anonymous.

In the early eighteenth century, the Jamaican surgeon and naturalist Henry Barham drew upon the island's vernacular knowledge to cultivate a correspondence and patronage relationship with Hans Sloane, physician, naturalist, and, after 1727, president of the Royal Society. Over the course of his 15-year correspondence with Sloane, the surgeon alternatively praised, critiqued, and expanded upon the physician's Catalogus Plantarum and natural history of the island. Sloane, who by the time the second volume of his natural history was published had not been to Jamaica for over 30 years, relied on Barham's expertise as he revised his text; the second volume of Sloane's natural history cited the surgeon over 90 times. $^{18}$ Barham's expertise derived from his ongoing investigations into the natural knowledge of all the island's former residents - Amerindians, Spaniards, and Spanish slaves. In his own surgical practice, Barham employed these older remedies alongside those he learned from the enslaved Africans he encountered on the island. Vernacular knowledge also provided the basis for his extensive correspondence with Sloane and the Royal Society. Diligent study of vernacular knowledge resulted in Barham's Hortus Americanus, one of the most complete compendiums of the vernacular names, remedies, and uses of Jamaican plants. As he explained to Sloane, his practical guide to Jamaican simples "sett forth the Known Vertues and experienced Qualitys as I gained them from Spaniards[,] Indians and Negroes." Throughout his Hortus and his correspondence, Barham acknowledged that his expertise on the uses for Jamaican plants was based upon extensive reliance on his local informants. All told, Barham referenced more than 50 instances of vernacular knowledge. Yet only once did Barham identify his indigenous or African informant by name. ${ }^{19}$

The anonymity of Barham's informants reinforced his position as the author of the knowledge that he reported to Sloane, the Royal Society, and the anticipated audience of his Hortus. Historians of science have noted the importance of identity for establishing the credibility of claims in early modern natural philosophy. The Royal Society, for example, included the names of the gentlemen who witnessed an experiment, trusting that the credibility of the individual gentlemen would translate into credibility for the experiment that they witnessed. Specificity - of the place, time, and identity of the observer - allowed natural philosophers to establish the veracity of their claims. Therefore anonymity reinforced the status of indigenous and African informants as non-authors. ${ }^{20}$

The single exception in Barham's texts - the one informant that he named serves only to reinforce this connection between identity and authorship. Barham described the Majoe plant as named for the

\footnotetext{
old negro woman ... who, with a simple decoction [of the plant], did wonderful cures in the most stubborn diseases, as the yaws, and in venereal cases, when the person has been given over as incurable by skilful physicians, because their Herculean medicines failed them; viz preparations of mercury and antimony. ${ }^{21}$
}

Majoe's renown in Jamaica as a talented healer was inscribed in the vernacular name for the plant she so skillfully employed. Like Majoe, most of the informants who were named by colonials were healers whose medical skill made them famous 
locally and who had made public the once secret remedy with which they were associated. For example, in 1729, the executive council of Virginia freed James Papaw, an enslaved man belonging to Frances Littlepage, in exchange for his secret remedy for "inveterate venereal Distempers." Similarly, in 1749, the South Carolina legislature awarded a slave named Caesar his freedom and an annual pension of $£ 100$ in exchange for his cures for poisons and snakebites. ${ }^{22}$ The fame of these freed men and, in particular, their cures traveled far beyond the confines of their local society. Caesar's remedies, which drew upon African, indigenous, and European medical traditions, were widely reprinted throughout the British Atlantic. His antidote for poison called for a decoction made from wild horehound, a species indigenous to North America, and plantain (plantago), a European plant so associated with colonists that Native Americans called it "white man's foot." Plantain was commonly used in European medicine, but Caesar's recipe used the plant in a manner more common in African or Native American medical traditions. ${ }^{23}$ "Caesar's cure" could be found in recipe books, especially in the American South, well into the nineteenth century. In exceptional cases such as those of Majoe and Caesar, when an indigenous or African healer revealed secret knowledge to the broader community, the individual's name reinforced the epistemological authority of the claim. The act of making known what was once secret constituted a discrete moment, revealed at a particular time and place, thereby providing the sort of specificity necessary to give credibility to a new knowledge claim.

The Jamaican physician and naturalist Anthony Robinson shared this tendency to acknowledge the authority of his testifiers but not identify them by name. In the course of his investigations as the governor's appointed botanist for the island, Robinson questioned Mr Westney, a tavern keeper in Knock Patrick, in the centralsouthern Jamaican parish of Vere. ${ }^{24}$ The publican assured the Jamaican doctor that the Rose Wood tree described in previous natural histories was common in the local woods. To demonstrate his claim, Westney sent a slave to fetch a branch of the tree. However, the slave "presently return'd with a Branch of a strange Tree, such as [Robinson] had never before seen neither the Rose Wood of Sloane nor the Candle Wood of Brown." Although the specimen obtained by Westney's slave was new to Robinson and, he implied, to the European corpus of Jamaican herbals, Robinson noted that local slaves were familiar with the plant. "The Clarendon Negroes," presumably of the adjoining Clarendon Parish, recognized it as a distinct tree and had a separate name for it, the "black Candle Wood." Robinson credited a local knowledge community - the blacks of the adjoining parish - with the ability to distinguish between varieties of trees that sojourning European naturalists had confused. Yet this superior understanding on the part of the "Clarendon Negroes" was presented as rooted in the community as a whole, rather than credited to a particular individual, such as the slave who obtained the specimen for Robinson. Crediting the know-how of the community as a whole was, in essence, a way of denying any one individual within that community the status as author of the knowledge claim. Instead it was Robinson, the local Jamaican physician, who fulfilled this role. ${ }^{25}$

Although Brooke did not indicate how he persuaded his Native American informant to share with him the secret of the Mattapany tea, other naturalists revealed that they exchanged money or goods in return for natural knowledge. John Clayton, for example, reported that Virginia Indians would cure Englishmen in 
exchange for a match coat or a few quarts of rum. Edward Bancroft gave slaves on neighboring plantations in Guiana a glass of rum for each snake they brought to him. Other naturalists paid slaves and Indians to gather rare plants or animals, and to reveal the virtues of local flora. ${ }^{26}$ In the context of seventeenth-century natural philosophy, Shapin notes that the social and economic relationship inherent to assistants' status as servants and employees prevented them from claiming credit for the discovery of new knowledge. By accepting remuneration, assistants and servants accepted the loss of their authorial voice and of ownership over the fruits of their labor. $^{27}$

The colonial context only served to intensify this appropriation. After all, the appropriation of the bodies and labor of others was one of the defining features of plantation societies. By employing their own slaves as assistants and paying others, colonial naturalists could appropriate vernacular knowledge about the natural world as their own. Furthermore, the legal status of slaves in plantation societies compromised their ability to be authors of new knowledge. As chattel, the labor intellectual or otherwise - of slaves was, by definition, owned by another. Such a status further undermined the ability of slaves to be the authors of new knowledge claims in the eyes of colonial naturalists.

The presence of enslaved and free black and Amerindian informants stood witness to the validity of new matters of fact about American nature. However, indigenous and African collaborators were not present in naturalists' texts as individuals, but as members of larger knowledge communities; as individuals they remained anonymous. In natural histories of British plantation societies, the corporate identity of African or indigenous sources, rather than that of the individual, was key to colonials' epistemological authority. Slaves and Indians did not, therefore, appear in naturalists' texts as fellow claimants or as independent authors of new knowledge. Rather, they appeared as necessary components of white naturalists' credibility - in essence, instruments of their knowledge creation.

\section{Translating vernacular knowledge}

William Hillary's 1766 medical treatise claimed that while the best European doctors had no reliable cure for yaws, Caribbean blacks "by long Observation and Experience" found a cure with the juices "of certain escarotic Plants ... which they keep as a Secret from the white People, but preserve among themselves by Tradition." 28 Hillary acknowledged the authority of Caribbean blacks regarding the local natural world. This understanding, however, was represented as rooted in the passive accumulation of information about the natural world passed down among Caribbean blacks over time, rather than the result of a particular experiment or observation that could be substantiated through specific circumstantial details. Naturalists such as Hillary suggested that vernacular knowledge was not knowledge on a par with their own because it was not certified by reasoned analysis and experiment. Colonial naturalists, therefore, frequently discussed the "observations" and "experience" of African slaves and Indians, but rarely their "knowledge."

Colonial naturalists credited the know-how, rather than the knowledge, of African and indigenous informants. A slave or Native American might recognize from experience the medicinal uses of a particular plant or be able to capture a rare bird. To colonial naturalists, however, such abilities derived from a jumble of 
observations, harmless superstitions, useful remedies, and dangerous poisons, rather than genuine knowledge. As Paula Findlen observes in the context of early modern Italian natural history: "Experience was not adequate unto itself, but required the proper intellectual framework to make it meaningful knowledge." ${ }^{29}$ While colonials acknowledged their indigenous and African informants' expertise in some areas, they suggested that their informants lacked the causal understanding necessary for it to be reliable knowledge. As evidence of this absence of understanding, naturalists claimed informants' know-how was not part of a broader intellectual framework. Others acknowledged the presence of an intellectual framework but claimed it comprised superstition or even diabolism.

In The Natural History of Carolina, Florida and the Bahama Islands, Mark Catesby frequently recorded how local Native Americans used the various plants he encountered during his sojourn in British North America. The naturalist explained that south-eastern Native Americans used the purple bindweed of Carolina against snakebites and believed a tonic prepared from cassena "restores lost Appetite, strengthens the Stomach, giving them Agility and Courage in War, \&c." Yet despite Catesby's frequent praise for Amerindian skill at using local plants to treat wounds and other ailments, he also criticized them as being "wholly ignorant in Anatomy and Phlebotomy." 30 Catesby saw the absence of medical practices that resembled those in fashion in Europe as evidence of the inferiority of indigenous medical practices, notwithstanding their efficacy. Naturalists such as Catesby sought to abstract indigenous and African uses of American nature from the complex spiritual and healing traditions of which they were a part. Rather than inquire into the world views and cosmologies associated with American simples, naturalists criticized what they perceived to be an absence of a medical theory behind local remedies. ${ }^{31}$

Similarly, Hans Sloane dismissed slave and indigenous knowledge as unsystematic, yet carefully recorded it throughout his Natural History of Jamaica. He recommended, for example, the Juncus cyperoides for the cure of a stomach ache and noted it was the most celebrated simple among Native Americans in the Bay of Honduras. The naturalist also recorded that leaves of the Santa Maria plant

are applied to the Head when it akes, or to any part of the Joints in the Gout, and are thought to ease pain in every affected part, and therefore this is esteemed as a very rare Remedy, by all Indians and Negroes, and most part of the Planters.

In spite of the respect accorded to the plant locally, Sloane dismissed Santa Maria leaves as no more efficacious than well-known European remedies. However, he still included a description of the local uses for the Santa Maria tree in his natural history. Throughout his work, Sloane proclaimed that while many Jamaican colonists praised the skill of local black and Indian doctors, he never saw any evidence to support such a claim. He grudgingly acknowledged their understanding of "the vertues of some few Simples." The naturalist, however, qualified even this begrudging praise by declaring that their "ignorance of Anatomy, Diseases, Method, \&c. renders even that knowledge of the vertues of Herbs, not only useless, but even sometimes hurtful to those who imploy them." 32 While Sloane reluctantly acknowledged the herbal expertise of Amerindians and enslaved and free Africans, he qualified even his half-hearted praise for their skill by arguing that such knowledge was dangerous without the intellectual framework in which he had been trained. 
Unlike Catesby and Sloane, John Clayton was a long-term resident of the New World, living in Virginia for more than 50 years. Yet he also pointed to the absence of an intellectual tradition resembling those current in Europe as evidence of the deficiencies of indigenous knowledge. In his letter read to the Royal Society in 1740 , Clayton argued that the medical practices of Virginia Indians were not worthy of the accolades others had showered upon them. The naturalist argued that Amerindians had "not much Skill in Surgery" and not enough "Knowledge in Physick as to let blood." Like Catesby and Sloane, he pointed to the absence of hallmarks of contemporary European medical practices - such as bloodletting - to support his claim for the absence of a valid intellectual system among Native Americans. While he acknowledged Indians' skill with simples, he dismissed it as the result of "only rude Experience arising from necesity, and never yet cultivated into the form of art." Clayton claimed that indigenous knowledge of simples in Virginia "seems to have been derived from random Experiments for they try any herb that is next at hand." Indigenous healing practices, according to the naturalist, did not reflect a complex and detailed body of knowledge, but rather the haphazard application of local plants. Ignoring the utilitarian ends of European medical traditions, Clayton argued that the practical purposes indigenous knowledge fulfilled disqualified it as a "form of art." Furthermore, while Virginia's Native Americans might have pragmatic natural know-how, Clayton suggested that they lacked the art or rational knowledgeability to turn know-how into knowledge. ${ }^{33}$

Edward Long similarly criticized African and indigenous healing traditions for what he perceived to be an absence of theory and suggested that they did not represent meaningful knowledge. According to Long's History of Jamaica, Jamaican slaves used about 30 different herbs but "generally apply them at random, without any regard to the particular symptoms of the disease; concerning which, or the operation of their materia medica, they have formed no theory." What success they enjoyed, Long suggested, resulted not from their medical traditions, but from either random chance or observations of animals. He argued that it was well known that Native Americans in the mainland learned the cure for rattlesnake bites by these means. Although Long's text is rightly infamous for its crude apology for slavery and its disparaging depiction of Jamaican blacks, his discussion of vernacular knowledge is in keeping with ideas articulated in other colonial texts, taken to their logical (and racist) extreme. Long's argument reflects what historian Londa Schiebinger calls the "mythologies of drug discoveries," in which "knowledge traveled up a rather anthropo- and Eurocentric Chain of Being, from animals (with their instinctive cures), to Amerindians," and eventually to Europeans. Barham, whom Long frequently cited, ascribed the discovery of the Balsam Capaiba to the sort of mythology of drug discovery articulated by Long. Barham claimed that Native Americans discovered the plant's virtues by watching "wild boars or hogs running to the tree when wounded, striking their tusks against the trunk, and the balsam, flowing out into their wounds, perfectly healed them." According to Long, the urge to try local plants to cure ailments was one common even to "brutes." Indigenous and enslaved knowledge about the natural world was thus the result of animal instinct and experience, in contrast to the reasoned theory that lay behind European science and medicine. $^{34}$

Robert James, author of $A$ Medical Dictionary, agreed that animals and humans shared an instinct to look for remedies in the natural world. For James, however, only 
the intervening hand of God could explain the secret knowledge of the meaner sort. Rather than chance, James was "inclined to believe, that many Medical Discoveries may have been brought about by Inspiration, that is, by the peculiar Direction of Providence." Without divine providence, how else could we explain the failure of "the Labours of a Multitude of Men, both of Learning and Abilities, who have spent their entire Lives in physical Researches, and after all the boasted Advantages of our Reason," when, "we find, to the Mortification of human Wisdom, that the most important Remedies have been discovered by Savages"? According to James, the illiterate occasionally had a "secret Impulse to apply unknown Simples to particular Disorders, without being able to give any Reason for their conduct." Indigenous and African medical discoveries, and vernacular knowledge more broadly, could be explained by God-given instinct rather than rationality. The success of indigenous simples reflected God's goodness, rather than the perceptual competence of Native Americans. However, if this divinely inspired instinct was successful, then reason could be used to suggest "their farther Use in similar Cases." While providence and instinct might reveal a powerful new simple, only "our Reason" - that of the European naturalist or physician - could hope to explain the efficacy of a particular remedy and suggest additional applications for it. ${ }^{35}$

To colonial observers of American nature, providential care, random chance, long experience, and brute instinct explained the genesis of the remedies used by peoples of African and Amerindian descent. Wedded to their own medical and intellectual traditions, colonial naturalists denied the possibility of a system or theory behind indigenous or African traditions of healing. As the South Carolina physician Alexander Garden explained in 1755, vernacular knowledge deserved their "very particular enquiry," but only "useful hints" might be gathered from among the collective know-how of peoples of Amerindian and African descent. These "hints" were clues which white, gentlemanly naturalists such as Garden needed to unravel. In their various texts, naturalists represented such knowledge as mere know-how resulting from "rude Experience," potentially accurate but without any intellectual framework behind it - not true knowledge. ${ }^{36}$

Colonials positioned themselves as not merely the brokers or go-betweens of American natural knowledge, but as alchemists of sorts, turning the base materials of local knowledge into something more precious. ${ }^{37}$ They suggested that their own expertise and ways of knowing were necessary in order to turn the "observations" and "hints" of blacks and Indians into meaningful knowledge. This work of transformation made colonial naturalists authors of this knowledge. A 1745 article in the Virginia Gazette claimed that "the Discovery of the Virtues of the most valuable Medicines, now in Use, are owing to the Observations of the Vulgar." As evidence, the author pointed to Jesuit's bark, guaiacum, ipecacuanha, Virginia snakeroot, and Seneca rattlesnake root. The article advised that:

For this Reason, a prudent Physician will always give Attention to Medicines in Use among the Vulgar, and he'll frequently discover thereby Things, which by all his Skill he could not have otherwise done. But then, after any notable Drugg has been thus discovered, a skillful Physician has great Advantages above others, in directing and observing the necessary Experiments for discovering all the Cases in which such Medicine is most likely to be most useful, or to be prejudicial. ${ }^{38}$ 
The Gazette warned its readers that while careful attention to local remedies would point the naturalist to potential new drugs, such observations were merely a beginning. The naturalist needed to combine such hints with the methods and knowledge derived from European medical and natural philosophical traditions. Only through "necessary Experiments" could vernacular knowledge become matters of fact.

By such experiments, naturalists made vernacular knowledge their own, moving the locus of authority from their African and Amerindian sources to empirical trials performed under their own control. Colonial naturalists sought to distinguish the experience of blacks and Indians that resulted in the collection of specimens and observations from the experiments they performed which revealed nature and tested the truth of that which experience and observation described. ${ }^{39}$ The Jamaican naturalist and physician Patrick Browne, for example, argued that through the "observations of the vulgar [they] by a long experience frequently learn both [the] genus and qualities" of local flora and fauna. Yet when the physician learned that enslaved Africans and Indians had long used the plant known locally as "wormgrass" as a vermifuge, he verified what long experience had revealed. Browne explained that he could affirm that the grass had a "peculiar efficacy in destroying worms," having undertaken "a great number of successful experiments." These trials demonstrated, Browne explained, that the grass killed worms "in so extraordinary a manner, that no other simple can be of equal efficacy in any other disease as this is in those that proceed from these insects." While Browne first learned of the healing properties of the worm-grass by observing its use among slaves and Indians, he verified its efficacy through trials under his own control. Browne represented himself as distilling vernacular knowledge - taking that which was defused throughout the community, testing and refining it through his experiments, and once found worthy, transmitting it to his European audience through his Civil and Natural History of Jamaica. $^{40}$

Empirical trials performed by gentlemen of the naturalist's acquaintance also served to authenticate indigenous and African knowledge. In 1717, the Jamaican surgeon Barham informed Sloane that while the root "Radix Fruticosa" was used by slaves to clean their teeth as Sloane noted in his Catalogus Plantarum, the London naturalist had missed its most important virtue. Jamaican slaves believed that the root prepared as a plaster was "most Sovereign Remedy that they Knoew Amongst all the Plants that comes within their Knowledge." As evidence, Barham referenced the "many Experiments" performed by an acquaintance, "an Honorable Coll[onel] In Liganoa." Barham explained that the colonel had made many decoctions of the root and used it to excellent success. Based on this evidence, Barham endorsed the virtues of the plant as ascribed to it by local enslaved Africans. ${ }^{41}$

The importance of empirical trials for establishing matters of fact can also be seen in cases in which the naturalist failed to do so. James Knight of Jamaica extolled the many natural commodities still to be discovered on the island, "some of which are only known to the Negroes." However, he explained that he was reluctant to speculate further, "not having made any Experiment, for want of Skill and knowledge in Simples." Similarly, in 1712, Thomas Walduck of Barbados promised his correspondent, the English apothecary and naturalist James Petiver, that although he was enclosing a list of plant names used by "Nurses, Old women and Negros," in the future he would "take care by some Experiment or other not to be 
imposed upon" by his informants. Without such verification, he implied, his descriptions of the natural world might not be credible. The minutes of the Royal Society confirm Walduck's fears. After Petiver presented Walduck's letter to the Royal Society in January 1714, members of the society declared that "the Capt. seemed to give too much Credit to the ill grounded Reports of the Vulgar." Without Walduck verifying and refashioning vernacular knowledge, it lacked credibility in the eyes of members of the Royal Society. Untranslated, vernacular knowledge could be thwarted in its transmission. ${ }^{42}$

\section{Conclusion}

For colonials such as Walduck, who were actively engaged in studying the natural wonders of the New World and presenting them to a European audience, thwarted knowledge remained a constant possibility. Their own epistemological authority uncertain, living in a colonial space thousands of miles from the metropole, and reliant on the vagaries of transatlantic travel to transport their specimens, observations, and letters, colonial naturalists knew well the often uncertain process of creating new knowledge. But when confronted with the question of whether their enslaved or indigenous collaborators could be the authors of knowledge about American nature, they made clear their own claims to authorship.

Unnamed and therefore unspecified, anonymous informants could not be the authors of the matters of fact to which they attested. Amerindians and enslaved and free Africans appeared in natural histories of British plantation societies as members of their respective knowledge communities, not as individual knowers. While not wholly invisible, they remained anonymous as individuals. If one of the hallmarks of empirical science was the description of an experiment done in a particular place at a particular time by a particular person, then denying the individuality of African or indigenous collaborators forestalled their ability to be authors, or even co-authors, of the matters of fact to which they testified. Instead, it was colonial naturalists who represented themselves as the originators of new knowledge about American nature through their acts of appropriation, translation, and transmission.

Colonial naturalists suggested that their African and indigenous collaborators provided them with only observations or descriptions of how nature behaved, without any of the theoretical or rational principles characteristic of reliable, universal knowledge. According to colonials, vernacular knowledge was not really knowledge at all. Like the scholasticism against which New Science first contended, vernacular knowledge was received through tradition and custom rather than tested through ocular witnessing and experimentation. While allegedly static, irrational, and even dangerous, vernacular knowledge also represented to colonials an often superior understanding of New World nature. Colonists believed that Native Americans, Africans, and African Americans had special access to nature's secrets and therefore were uniquely placed to vouch for its properties. But it required colonial naturalists to verify vernacular knowledge through trials and experiments before it could become the stable, universal knowledge suitable for a European audience.

Although colonials asserted the superiority of the intellectual systems with which they investigated the natural world, their dependence on indigenous and African knowledge was still fraught with anxiety. Colonial naturalists' insistence on their own 
rational knowledgeability and the emphasis they placed on their experimentation represents an attempt to distance themselves from the blacks and Indians upon whom they so intimately depended. For to trust someone is to accord them a level of power and honor; to trust a slave or Indian would seem to be at odds with the systems of power undergirding colonization and slavery. ${ }^{43}$

As the translators of vernacular knowledge, colonials saw themselves as the crucial link bringing the hidden secrets of New World nature out into the open of European natural philosophy. More than just conduits, they were creators of new knowledge. Yet like any translation, once taken out of its context, much of the original meaning was lost. For colonial naturalists, this decontextualization removing information about the material uses and characteristics of American flora and fauna from the intellectual system of which they were a part - was a key component of the process by which colonials reinscribed vernacular knowledge as their own. Yet it remains for scholars to try to recapture that which has been lost in translation.

\section{Notes on contributor}

Kathleen Murphy is Assistant Professor of History at California Polytechnic State University, San Luis Obispo, California, USA. This article is part of a larger book project that examines the networks of natural history in eighteenth-century British plantation societies from the Chesapeake to the Caribbean.

\section{Notes}

1. Delbourgo, "Fugitive Colours"; Drayton, Nature's Government, 92; Parrish, American Curiosity, 22, 215-306; and Schiebinger, Plants and Empire.

2. Schaffer, "Scientific Discoveries," 389. See also Biagioli and Galison, Scientific Authorship.

3. Dear, "Totius in Verba," 154-6; Lux and Cook, "Closed Circles"; Shapin, Social History of Truth, 126-92, 355-407; and Shapin and Schaffer, Leviathan.

4. I use the term "colonial naturalist" to indicate individuals in British plantation societies who were actively engaged in the study of the natural world. This participation typically took the form of sending or receiving correspondence relating to the natural world, collecting natural curiosities, or publishing scientific observations in local newspapers or in the transactions of scientific societies such as the Royal Society of London. Few, if any, of these individuals could be considered professional naturalists in the modern sense of the term. However, in this period before the professionalization of science, such individuals were few and far between, even in Europe.

5. Parrish, American Curiosity, 215-306 (217). See also Carney, Black Rice; Carney and Rosomoff, Shadow of Slavery; Chaplin, Subject Matter; Delbourgo, "Fugitive Colours"; Delbourgo, A Most Amazing Scene, 183-9; Delbourgo, "Slavery"; Parsons, "Medical Encounters and Exchange"; Robinson, "New Worlds, New Medicines"; Safier, "Global Knowledge"; Schiebinger, Plants and Empire; Tobin, Colonizing Nature; and Weaver, Medical Revolutionaries.

6. Brooke, "Letter"; Brooke, "Thermometical Account"; The Gentleman's Magazine 22 (1752): 182, 208, 278; The Gentleman's Magazine 25 (1755): 54; The Gentleman's Magazine 26 (1756): 32; The Gentleman's Magazine 33 (1763): 541; and Steiner, "Dr Richard Brooke."

7. Royal Society of Arts, Guard Books, 1755-70, VI: 121, February 17, 1762. The London Society for the Encouragement of Arts, Manufactures and Commerce, also known as the Society of Arts, was founded by William Shipley in 1754; see Allan and Abbott, Virtuoso Tribe. For the cultural and political significance of naming, see Schiebinger, Plants and Empire, 194-225. 
8. Henry Baker, who presented Brooke's letter to the Royal Society of Arts, reported that he had tried the tea several times and had served it to "three different Companies of Ladies ... and tho' they were greatly prejudiced against it, on tasting they liked it well, each of them drank a Cup or two, and some of them would drink no other Tea." Royal Society of Arts, Guard Books, 1755-70, VI: 121, February 17, 1762.

9. Greene, Diary, 301. See also Berlin, Many Thousands Gone, 42-3, 123-6; Genovese, Roll, Jordan, Roll, 38-41; Morgan, Slave Counterpoint, 263-4; Morris, Southern Slavery, 22948; and Olwell, Masters, Slaves, and Subjects, 57-101. The specific legal disabilities experienced by individuals of Amerindian and African descent varied by colony and over time, but the idea that the testimony of these groups was suspect and, in most cases, inadmissible remained constant. In certain "pregnant circumstances" (such as an alleged slave revolt), exceptions could be made to allow the testimony of blacks and Indians against non-whites.

10. Brown, Reaper's Garden, 149-52; Carney, Black Rice; Carney and Rosomoff, Shadow of Slavery; Fett, Working Cures, 60-76; Galvin, "Decoctions for Carolinians," 81-2; Handler, "Slave Medicine and Obeah"; Morgan, Slave Counterpoint, 222, 242, 479-84, 493, 619; Parrish, "Diasporic African Sources," 283; Schiebinger, Plants and Empire, 7980; Sobel, World They Made Together, 78; Stewart, "Nature Suffers to Groe," 134-6, 1416, 178-9; Wood, Black Majority, 120-3; and Wood, "People's Medicine."

11. Hughes, Natural History of Barbados, 56. For early modern usage of "vulgar," see the Oxford English Dictionary Online, 2nd ed. (1989), http://www.oed.com.

12. Lawson, History of Carolina, 133; Henry Barham to Hans Sloane, April 30, 1724, Sloane 4047, fol. 165, British Library, London. For Sloane's description of this plant, see Voyage to the Islands, 1: 206-7. Hereafter this work will be referred to by its more common title, Natural History of Jamaica.

13. Tilley, "Global Histories, Vernacular Science," 117. See also Fissell, Vernacular Bodies, 6-7.

14. This idea of vernacular knowledge is similar to the concept of appropriation as articulated by Fissell and Cooter. They define appropriation as "the cultural acquisition of knowledges, or the ways in which they are borrowed from one social setting and reformulated in another" ("Exploring Natural Knowledge," 146; see also Chartier, "Culture as Appropriation").

15. Gilbert Falconer to Cromwell Mortimer, May 14, 1733, Royal Society Letterbook 20, 332-7, quoted in Stearns, Science in the British Colonies, 275-6; Knight, "History of Jamaica."

16. Shapin, "Invisible Technicians"; Shapin, Social History of Truth, 355-407 ("ghost and the machine," 372); and Shapin and Schaffer, Leviathan, esp. 76-9. For "invisible assistants" in early modern Italian natural history, see Findlen, Possessing Nature, 170-9, 224.

17. Parrish, American Curiosity, 18, 249, 288.

18. Sloane, Catalogus Plantarum; Sloane, Natural History of Jamaica (1725). For the patronage relationship between Barham and Sloane, see Murphy, "Portals of Nature," $28-81$.

19. Barham, Hortus Americanus; Henry Barham to Hans Sloane, April 17, 1718, Sloane 4045, fol. 108, British Library, London. Published posthumously, Hortus Americanus was likely written in 1711.

20. Dear, "Totius in Verba," esp. 152; Shapin, Social History of Truth, 226-7; and Shapin and Schaffer, Leviathan, 58.

21. Barham, Hortus Americanus, 96.

22. McIllwaine, Hall, and Hillman, Executive Journals, 4: 199, April 23, 1729; Barbados Gazette, January 2, 1733, reprinted in Keimer, Caribbeana, 1: 258; Fett, Working Cures, 64, 68-9; Morgan, Slave Counterpoint, 625; and Parrish, American Curiosity, 285-8.

23. Galvin, "Decoctions for Carolinians," 82-7; Millspaugh, American Medicinal Plants, 41922; Moerman, Geraniums for the Iroquois, 161-2; South Carolina Gazette, May 14, 1750; Usher, Dictionary of Plants, 244; and Virginia Gazette and Weekly Advertiser, July 4, 1789. Caesar's and other freed slaves' cures for snakebites also incorporated aspects of indigenous and European medicine. Caesar's cure for snakebites similarly used horehound and plantain, but the patient was also instructed to dress his wound with tobacco important in Native American healing traditions - soaked in rum. Plantago is believed to 
have been introduced to the South-East by Europeans and should not be confused with musa paradisiaca, the unrelated banana-like fruit commonly known as plantain.

24. Robinson received a salary of $£ 200$ to collect natural curiosities for the Royal Society. He also compiled extensive notes and drawings for a natural history of the island that was never published. See Burnard, Mastery, Tyranny, and Desire, 102; Cockerell, "Little Known Jamaican Naturalist"; Cundall, "Dr Anthony Robinson"; and Sheridan, Doctors and Slaves, 66.

25. Robinson, General Index, 1, Book A: 35. Robinson referred to the absence of the plant in two popular natural histories of Jamaica: Sloane, Natural History of Jamaica (London, 1707, 1725) and Browne, Natural History of Jamaica. Browne described the "White Candlewood or Rose-wood" as native to the Jamaican parishes of St Ann and Port Royal. He reported that Jamaicans used it as a mild astringent and vulnerary to heal wounds, and that it was also prized as "one of the most valuable timber-trees in the island ... and in great vogue among our cabinetmakers" (Browne, Natural History of Jamaica, 208-9).

26. Clayton, "'Aborigines of the Country,", 22, 25; Bancroft, Natural History of Guiana, 220. See also Barham, Hortus Americanus, 18, 86, 148, 209; "John Banister's Papers Relating to Natural History," 1678-80, Sloane 4002, fol. 25, British Library, London; and John Frere to John Hatley Norton, April 1, 1768, in Norton Mason, John Norton and Sons, 42-4. For more on naturalists paying informants in the Atlantic world, see Schiebinger, Plants and Empire, 90-3.

27. Shapin, Social History of Truth, 392-403.

28. Hillary, Changes of the Air, 341.

29. Findlen, Possessing Nature, 157.

30. Catesby, Natural History of Carolina, 1: xv, 35; 2: 57.

31. See also Cook, "Global Economies," 117-18; Cook, Matters of Exchange, 175-225; Robinson, "New Worlds, New Medicines"; Tobin, Colonizing Nature, 26, 32-55, 168-97; and Walker, "Acquisition and Circulation," 268-9.

32. Sloane, Natural History of Jamaica, 1: cxli, 121, 136. Physicians and authors made similar critiques in early modern Europe and colonial Latin America. See Eamon, Science, 140-1, 259-63; Pardo, "Power to Heal."

33. Royal Society of London, Journal Books of Scientific Meetings, Collections, 17: 218-19, June 19, 1740; Berkeley and Berkeley, John Clayton. John Ellis of Jamaica also ascribed slave medical knowledge to luck. See John Ellis [of Jamaica] to John Ellis [of London], July 26, 1772, Ellis Papers, Linnean Society Archives, London .

34. Long, History of Jamaica, 2: 380-1; Schiebinger, Plants and Empire, 81-2; Barham, Hortus Americanus, 11-12. Schiebinger suggests that this "anthropo- and Eurocentric Chain of Being" also reflected imperial rivalries. The French naturalist Charles-Marie de La Condamine described the chain of discovery for the Jesuit's Bark as beginning with "American lions," then transmitted to Amerindians, next to the Spanish, and ultimately to the French (Plants and Empire, 81).

35. James, Medical Dictionary, 1: i.

36. Alexander Garden to John Ellis, March 25, 1755, in Smith, Correspondence of Linnaeus, 1: 351.

37. For the role of go-betweens in the history of science, see Schaffer et al., Brokered World.

38. "Some reflections," 1-2.

39. By experiments, colonial naturalists meant something more akin to case histories. Typically, it indicated that they had tried a particular cure and witnessed its results, rather than referred to the controlled medical tests that began to be employed in the late eighteenth century. See Dear, "Totius in Verba"; Eamon, "Science and Popular Culture," esp. 483-4; Findlen, Possessing Nature, 201; and Schiebinger, "Human Experimentation."

40. Browne, Natural History of Jamaica, ccclxxix, 156. For physicians experimenting to verify slave remedies, see Fett, Working Cures, 65, 151-4; Schiebinger, "Human Experimentation." These experimental inquiries could take a gruesome turn when colonial naturalists used slaves as test subjects. See, for example, Henry Barham to Hans Sloane, November 4, 1717, Sloane 4045, fol. 68, British Library, London; Long, History of Jamaica, 3: 838-9; and Thornton, "Account of Lettsom's Island," 14: reel 5, 10. 
41. Henry Barham to Hans Sloane, December 11, 1717, Sloane 4045, fols. 77-9, British Library, London; Sloane, Catalogus Plantarum, 214.

42. Knight, "History of Jamaica," 147v; Thomas Walduck to James Petiver, September 17, 1712, Sloane 2302, fols. 25-6, British Library, London; and Royal Society of London, Journal Books of Scientific Meetings, Collections, 10: 527, January 7, 1714. See also Parsons, "Medical Encounters and Exchange"; Safier, "Fruitless Botany," esp. 205.

43. Shapin, Social History of Truth, 38.

\section{References}

Allan, D.G.S., and John L. Abbott, eds. The Virtuoso Tribe of Arts and Sciences: Studies in the Eighteenth-Century Work and Membership of the London Society of Arts. Athens: University of Georgia Press, 1992.

Bancroft, Edward. An Essay on the Natural History of Guiana. London: T. Becket and P.A. De Hondt, 1769.

Barham, Henry. Hortus Americanus: Containing an Account of the...Vegetable Productions of South-America and the West-India Islands, and Particularly the Island of Jamaica. Kingston: Alexander Aikman, 1794.

Berkeley, Edmund, and Dorothy Smith Berkeley. John Clayton: Pioneer of American Botany. Chapel Hill: University of North Carolina Press, 1963.

Berlin, Ira. Many Thousands Gone: The First Two Centuries of Slavery in North America. Cambridge, MA: Harvard University Press, 1998.

Biagioli, Mario, and Peter Galison, eds. Scientific Authorship: Credit and Intellectual Property in Science. New York: Routledge, 2003.

Brooke, Richard. "A Letter from Mr Rich Brooke, Surgeon, to James Parsons, MD, Secretary to the Royal Society for Foreign Correspondence, Concerning Inoculation." Philosophical Transactions 47 (1757): 470-2.

Brooke, Richard. "A Thermometical Account of the Weather, for One Year, Beginning September 1753. Kept in Maryland, by Mr Richard Brooke, Physician and Surgeon in that Province. Communicated by Mr Henry Baker, FRS.” Philosophical Transactions 51 (1759): $58-69$.

Brown, Vincent. The Reaper's Garden: Death and Power in the World of Atlantic Slavery. Cambridge, MA: Harvard University Press, 2008.

Browne, Patrick. The Civil and Natural History of Jamaica. London, 1756.

Burnard, Trevor. Mastery, Tyranny, and Desire: Thomas Thistlewood and His Slaves in the Anglo-Jamaican World. Chapel Hill: University of North Carolina Press, 2004.

Carney, Judith Ann. Black Rice: The African Origins of Rice Cultivation in the Americas. Cambridge, MA: Harvard University Press, 2001.

Carney, Judith Ann, and Richard Nicholas Rosomoff. In the Shadow of Slavery: Africa's Botanical Legacy in the Atlantic World. Berkeley: University of California Press, 2009.

Catesby, Mark. The Natural History of Carolina, Florida and the Bahama Islands. 2 vols. London, 1729-47.

Chaplin, Joyce. Subject Matter: Technology, the Body, and Science on the Anglo-American Frontier, 1500-1676. Cambridge, MA: Harvard University Press, 2001

Chartier, Roger. "Culture as Appropriation: Popular Cultural Uses in Early Modern France." In Understanding Popular Culture: Europe from the Middle Ages to the Nineteenth Century, ed. Steven L. Kaplan, 229-53. Berlin: Mouton, 1984.

Clayton, John. " 'The Aborigines of the Country.' John Clayton to Nehemiah Grew, 1687.” In The Reverend John Clayton: A Parson with a Scientific Mind, His Scientific Writings and Other Related Papers, ed. Edmund and Dorothy Smith Berkeley, 21-39. Charlottesville: University of Virginia Press, 1965.

Cockerell, T.D.A. "A Little Known Jamaican Naturalist, Dr Anthony Robinson." American Naturalist 28, no. 333 (1894): 775-80.

Cook, Harold. "Global Economies and Local Knowledge in the East Indies: Jacobus Bontius Learns the Facts of Nature." In Colonial Botany: Science, Commerce, and Politics in the Early Modern World, ed. Londa Schiebinger and Claudia Swan, 100-18. Philadelphia: University of Pennsylvania Press, 2005. 
Cook, Harold. Matters of Exchange: Commerce, Medicine, and Science in the Dutch Golden Age. New Haven, CT: Yale University Press, 2007.

Cundall, Frank. "Dr Anthony Robinson, of Jamaica." Journal of Botany 60 (1922): 49-52.

Dear, Peter. "Totius in Verba: Rhetoric and Authority in the Early Royal Society." Isis 76, no. 2 (1985): 145-61.

Delbourgo, James. "Fugitive Colours: Shamans' Knowledge, Chemical Empire and Atlantic Revolutions." In The Brokered World: Go-Betweens and Global Intelligence, 1770-1820, ed. Simon Schaffer, Lissa Roberts, Kapil Raj, and James Delbourgo, 271-320. Sagamore Beach, MA: Science History Publications, 2009.

Delbourgo, James. A Most Amazing Scene of Wonders. Cambridge, MA: Harvard University Press, 2006.

Delbourgo, James. "Slavery in the Cabinet of Curiosities: Hans Sloanes' Atlantic World." British Museum. http://www.britishmuseum.org/pdf/delbourgo\%20essay.pdf.

Drayton, Richard. Nature's Government: Science, Imperial Britain, and the "Improvement" of the World. New Haven, CT: Yale University Press, 2000.

Eamon, William. "Science and Popular Culture in Sixteenth Century Italy: The 'Professors of Secrets' and Their Books." Sixteenth Century Journal 16, no. 4 (1985): 471-85.

Eamon, William. Science and the Secrets of Nature: Books of Secrets in Medieval and Early Modern Culture. Princeton: Princeton University Press, 1994.

Fett, Sharla M. Working Cures: Healing, Health, and Power on Southern Slave Plantations. Chapel Hill: University of North Carolina Press, 2002.

Findlen, Paula. Possessing Nature: Museums, Collecting, and Scientific Culture in Early Modern Italy. Berkeley: University of California Press, 1994.

Fissell, Mary E. Vernacular Bodies: The Politics of Reproduction in Early Modern England. Oxford: Oxford University Press, 2004.

Fissell, Mary E., and Roger Cooter. "Exploring Natural Knowledge: Science and the Popular." In The Cambridge History of Science: Volume 4, Eighteenth-Century Science, ed. Roy Porter, 129-58. Cambridge: Cambridge University Press, 2003.

Galvin, Mary L. "Decoctions for Carolinians: The Creation of a Creole Medicine Chest in Colonial South Carolina." In Creolization in the Americas, ed. David Buisseret and Steven G. Reinhardt, 63-87. College Station: Texas A\&M University Press, 2000.

Genovese, Eugene D. Roll, Jordan, Roll: The World the Slaves Made. New York: Vintage, 1976.

Greene, Jack P., ed. The Diary of Colonel Landon Carter of Sabine Hall, 1752-1778. Vol. 1. Charlottesville: University of Virginia Press, 1965.

Handler, Jerome. "Slave Medicine and Obeah in Barbados, Circa 1650 to 1834." New West Indian Guide 74, no. 1-2 (2000): 57-90.

Hillary, William. Observations on the Changes of the Air, and the Concomitant Epidemical Diseases in the Island of Barbadoes. London: L. Hawes, W. Clarke, and R. Collins, 1766.

Hughes, Griffith. The Natural History of Barbados: In Ten Books. London: Printed for the Author, 1750.

James, Robert. A Medical Dictionary. 3 vols. London: Printed for T. Osbourne, sold by J. Roberts, 1743-5.

Keimer, Samuel. Caribbeana: Containing Letters and Dissertations, together with Political Essays, on Various Subjects and Occasions. 2 vols. London: T. Osborne and W. Smith, 1741.

Knight, James. "The Natural, Moral, and Political History of Jamaica, etc. from the Earliest Times to 1742." Add. MS 12, 419, British Library, London.

Lawson, John. The History of Carolina: Containing the Exact Description and Natural History of that Country... London: W. Taylor and J. Baker, 1714.

Long, Edward. The History of Jamaica. 3 vols. London: T. Lowndes, 1774.

Lux, David S., and Harold J. Cook. "Closed Circles or Open Networks? Communicating at a Distance during the Scientific Revolution." History of Science 36, no. 112 (1998): 179-211.

McIllwaine, H.R., W.L. Hall, and B.J. Hillman, eds. Executive Journals of the Council of Colonial Virginia, 1680-1775. 6 vols. Richmond: Virginia State Library, 1925-66.

Millspaugh, Charles F. American Medicinal Plants. New York: Dover, 1974.

Moerman, Daniel E. Geraniums for the Iroquois: A Field Guide to American Indian Medicinal Plants. Algonac, MI: Reference Publications, 1981. 
Morgan, Philip D. Slave Counterpoint: Black Culture in the Eighteenth-Century Chesapeake and Lowcountry. Chapel Hill: University of North Carolina Press, 1998.

Morris, Thomas D. Southern Slavery and the Law, 1619-1860. Chapel Hill: University of North Carolina Press, 1996.

Murphy, Kathleen S. "Portals of Nature: Networks of Natural History in Eighteenth-Century British Plantation Societies." PhD diss., Johns Hopkins University, 2007.

Norton Mason, Frances, ed. John Norton and Sons, Merchants of London and Virginia: Being the Papers from their Counting House for the Years 1750 to 1795. 2nd ed. Newton Abott: David \& Charles, 1968.

Olwell, Robert. Masters, Slaves, and Subjects: The Culture of Power in the South Carolina Low Country, 1740-1790. Ithaca: Cornell University Press, 1998.

Pardo, Osvaldo. "Contesting the Power to Heal: Angels, Demons, and Plants in Colonial Mexico." In Spiritual Encounters: Interactions between Christianity and Native Religions in Colonial America, ed. Nicholas Griffiths and Fernando Cervantes, 163-84. Birmingham: University of Birmingham Press, 1999.

Parrish, Susan Scott. American Curiosity: Cultures of Natural History in the Colonial British Atlantic World. Chapel Hill: University of North Carolina Press, 2006.

Parrish, Susan Scott. "Diasporic African Sources of Enlightenment Knowledge." In Science and Empire in the Atlantic World, ed. James Delbourgo and Nicholas Dew, 281-310. New York: Routledge, 2008.

Parsons, Chris. "Medical Encounters and Exchange in Early Canadian Missions." Scientia Canadensis 31, no. 1-2 (2008): 49-66.

Robinson, Anthony. General Index and Description of Plants. Vol. 1 of Description of Jamaica Fauna and Flora. Unpublished manuscript. Botany Library, Natural History Museum, London, on loan from the Institute of Jamaica.

Robinson, Martha. "New Worlds, New Medicines: Indian Remedies and English Medicine in Early America." Early American Studies 3, no. 1 (2005): 94-110.

Royal Society of Arts. "The American Correspondence of the Royal Society of Arts, London, 1755-1840." Guard Books, 1755-70 and Loose Archives, 1755-1840, Micro Methods, Wakefield, 1963[?].

Royal Society of London, Journal Books of Scientific Meetings. Collections from the Royal Society, 1660-1800. 35 vols. Frederick, MD: University Publications of America, 1985.

Safier, Neil. "Fruitless Botany: Joseph de Jussieu's South American Odyssey." In Science and Empire in the Atlantic World, ed. James Delbourgo and Nicholas Dew, 203-24. New York: Routledge, 2008.

Safier, Neil. "Global Knowledge on the Move: Itineraries, Amerindian Narratives, and Deep Histories of Science." Isis 101, no. 1 (2010): 133-45.

Schaffer, Simon. "Scientific Discoveries and the End of Natural Philosophy." Social Studies of Science 16, no. 3 (1986): 387-420.

Schaffer, Simon, Lissa Roberts, Kapil Raj, and James Delbourgo, eds. The Brokered World: Go-Betweens and Global Intelligence, 1770-1820. Sagamore Beach, MA: Science History Publications, 2009.

Schiebinger, Londa. "Human Experimentation in the Eighteenth Century: Natural Boundaries and Valid Testing." In The Moral Authority of Nature, ed. Lorraine Daston and Fernando Vidal, 384-408. Chicago: University of Chicago Press, 2004.

Schiebinger, Londa. Plants and Empire: Colonial Bioprospecting in the Atlantic World. Cambridge, MA: Harvard University Press, 2004.

Shapin, Steven. "Invisible Technicians." American Scientist 77, no. 6 (1989): 554-63.

Shapin, Steven. Social History of Truth: Civility and Science in Seventeenth-Century England. Chicago: University of Chicago Press, 1994.

Shapin, Steven, and Simon Schaffer. Leviathan and the Air-Pump: Hobbes, Boyle, and the Experimental Life. Princeton: Princeton University Press, 1985.

Sheridan, Richard. Doctors and Slaves: A Medical and Demographic History of Slavery in the British West Indies, 1680-1834. Cambridge: Cambridge University Press, 1985.

Sloane, Hans. Catalogus Plantarum quae in Insula Jamaica. London: D. Brown, 1696. 
Sloane, Hans. A Voyage to the Islands Madera, Barbados, Nieves, S. Christophers and JAMAICA, with the Natural History. . of the Last of those Islands. 2 vols. London: B.M., $1707-25$.

Smith, James Edward, ed. A Selection of the Correspondence of Linnaeus, and Other Naturalists, from the Original Manuscripts. 2 vols. London, 1821.

Sobel, Mechal. The World They Made Together: Black and White Values in Eighteenth-Century Virginia. Princeton: Princeton University Press, 1987.

"Some Reflections on Dr. Berkley's Treatise on Tar-Water adapted to Diseases frequent in America." Virginia Gazette [Parks], May 23, 1745.

Stearns, Raymond Phineas. Science in the British Colonies of America. Urbana: University of Illinois Press, 1970.

Steiner, Bernard C. "Dr Richard Brooke, the First Scientific Observer in Maryland." Johns Hopkins Hospital Bulletin 15 (1904): 294-6.

Stewart, Mart A. "What Nature Suffers to Groe": Life, Labor, and Landscape on the Georgia Coast, 1680-1920. Athens: University of Georgia Press, 1996.

Thornton, William. "Some Account of Lettsom's Island - and Some of Its Productions, in a Letter to John Coakley Lettsom, MD, FRS \&c." William Thornton Papers, Manuscript Division, Library of Congress, Washington, DC.

Tilley, Helen. "Global Histories, Vernacular Science, and African Genealogies; or, Is the History of Science Ready for the World?" Isis 101, no. 1 (2010): 110-19.

Tobin, Beth Fowkes. Colonizing Nature: The Tropics in British Arts and Letters, 1760-1820. Philadelphia: University of Pennsylvania Press, 2005.

Usher, George. Dictionary of Plants Used by Man. New York: Hafner Press, 1974.

Walker, Timothy. "Acquisition and Circulation of Medicinal Knowledge within the Early Modern Portuguese Colonial Empire." In Science in the Spanish and Portuguese Empires, 1500-1800, ed. Daniela Bleichmar, Paula De Vos, Kristine Huffine, and Kevin Sheehan, 247-70. Stanford: Stanford University Press, 2009.

Weaver, Karol K. Medical Revolutionaries: The Enslaved Healers of Eighteenth-Century Saint Domingue. Urbana: University of Illinois Press, 2006.

Wood, Peter H. Black Majority: Negroes in Colonial South Carolina, from 1670 through the Stono Rebellion. New York: W.W. Norton, 1974.

Wood, Peter H. "People's Medicine in the Early South." Southern Exposure 6, no. 2 (1978): $50-3$. 